\title{
LUCES Y SOMBRAS DE MADRID EN LA NARRATIVA DE PEREDA $^{1}$
}

\author{
Raquel GUTIÉRREZ SEBASTIÁN \\ Universidad de Cantabria
}

\section{RESUMEN}

El trabajo analiza la visión negativa que de Madrid y sus gentes aparece en gran parte de las narraciones de José María de Pereda, desde sus primeros artículos costumbristas a novelas de plenitud como Pedro Sánchez (1883). En estas obras el novelista va perfilando una imagen de la capital de España cuajada de tópicos negativos y subordinada a sus intereses ideológicos, salpicada de elementos del costumbrismo literario y tamizada por su «conservadurismo periférico», que consideraba moralmente superior el mundo rural y que se ensañaba contra los vicios que anidaban en el cortesano, aunque un estudio detallado revela que esa imagen esencialmente negativa de Madrid es un prisma de varias caras que conviene detallar.

Palabras clave: Narrativa siglo XIX- Pereda-Madrid-imagen literaria.

\section{ABSTRACT}

The work analyzes the negative vision that of Madrid and his peoples appears largely of Jose Maria de Pereda's stories, from his first articles authors of novels of manners to novels of fullness as Pedro Sanchez (1883). In these works the novelist is outlining an image of the capital of Spain studded with topics negative and subordinated to his ideological interests.

Key words: Narrative-XIX century-Pereda-Madrid-Literary picture.

1. Es una Investigación llevada a cabo dentro del proyecto «Análisis de la literatura ilustrada del XIX» (Ref: FFI2008-00035) financiado por el Ministerio de Ciencia e Innovación (2009-2011).

Anales, 24, 2012, pp. 125-140 
Antimadrileñismo es el término que mejor puede definir la visión literaria de Madrid y sus gentes que aparece en gran parte de las narraciones de José María de Pereda (1833-1906). Desde sus primeros artículos costumbristas como Suum cuique, perteneciente a Escenas montañesas (1864), hasta los textos satíricos de Tipos trashumantes $(1877)^{2}$ o las primeras novelitas cuyo ambiente es el de la corte, como La mujer del César, incluida en Bocetos al temple (1876) y especialmente en sus obras de plenitud como Pedro Sánchez (1883) o La Montálvez (1888), el novelista va perfilando una imagen de la capital de España cuajada de tópicos negativos y subordinada a sus intereses ideológicos, salpicada de elementos del costumbrismo literario y tamizada por su «conservadurismo periférico», que consideraba moralmente superior el mundo rural y que se ensañaba contra los vicios que anidaban en el cortesano ${ }^{3}$. Pero esta imagen esencialmente negativa de Madrid es un prisma de varias caras que conviene analizar con detenimiento; a este propósito dedicaremos las siguientes páginas.

\section{MADRID FRENTE A LA ALDEA}

Como han señalado Clarke y especialmente González Herrán (Clarke: 1969; González Herrán: 1990, 1997 y 2007) uno de los tópicos más reiterados en la narrativa del escritor de Polanco es la confrontación entre la corte y la aldea, recreado literariamente a través de los viajes de los protagonistas de sus relatos de la aldea a Madrid o viceversa, lo que le permite al novelista contraponer ante el lector ambos escenarios. Este motivo argumental vertebra la trayectoria narrativa del escritor, hasta el punto de que, como ha propuesto González Herrán (2007: 62), podría hacerse un estudio de conjunto sobre su presencia en las obras de Pereda.

La imagen del mundo madrileño recreado en las ficciones peredianas está muy mediatizada por esa necesidad de contrastar la corte y la Montaña y se presenta en forma de un doble y contrapuesto itinerario: desde el pueblo a la capital y desde Madrid a la aldea.

2. Indica García Castañeda en su edición de este libro en las Obras completas de Tantín que: «Resiente la actitud de arrogante superioridad que traen los madrileños aunque sean pobre gente, el que todos hablen del veraneo como un exilio, que hallen faltas en todo, que hagan de menos a los santanderinos y que suspiren por «su» Mdrid, comportándose así como acérrimos provincianos.» (García Castañeda,1989: XI)

3. En el relato Los hombres de pro, incluido en Bocetos al temple, aparece también el espacio urbano madrileño, pero por ser fundamentalmente una sátira del arribismo político, la imagen de Madrid se circunscribe casi únicamente a los ámbitos políticos, tal como hemos estudiado en trabajos anteriores (Gutiérrez Sebastián: 2011), por lo que no lo incluimos en este estudio. 
Así sucede en el artículo Suum cuique, en el que este viaje parte de una idealización del espacio madrileño o rural y termina en un amargo desengaño para los dos personajes que viajan, el mayorazgo aldeano Silvestre Seturas y su amigo madrileño, a la vez que permite al Pereda costumbrista jugar con la técnica del perspectivismo a la hora de presentar Madrid, y colocar así varias imágenes superpuestas del escenario cortesano: la inicial de Silvestre Seturas, la de su desengaño final y la imagen negativa de Madrid del cortesano cuando decide retirarse a la aldea ${ }^{4}$.

En efecto, la primera impresión de la corte que percibe el lector en este texto es transmitida a través del personaje del mayorazgo montañés, y es una imagen falseada por la lejanía de la mirada sobre Madrid, evocada desde la aldea, ya que el personaje dice que se imagina la capital «vista desde el rincón de mi cocina» (p. 124)5 y porque en el magín de Seturas se dibuja una ciudad soñada que ha obtenido de su lectura de los periódicos:

Don Silvestre no veía en el diario de Madrid un papel más o menos grande, con la impresión de unas letras de plomo colocadas mecánicamente, [...]; el mayorazgo veía en él una idea fuera de todo contacto con lo humano, el destello de una inteligencia sobrenatural, ajena completamente a la vida civil; el periódico del cirujano era para él el catecismo, el Evangelio, un catálogo de verdades inconcusas, indiscutibles.» (p. 111).

El tópico del contraste entre la corte y la aldea, en definitiva una recreación literaria del menosprecio de corte y alabanza de aldea de Fray Antonio de Guevara, aparece desde los momentos iniciales de este relato, puesto que Madrid representa para Pereda la modernidad que amenaza la tradición (Pérez Gutiérrez, 1975:131-180), depositada en un mundo rural idealizado y opuesto a la corte.

En esta primera visión de Madrid que desde la distancia de su aldea forja el aldeano montañés, se dibuja un agradable mundo cortesano al que mentalmente opone Seturas el reducto de su pueblo:

4. Esa dualidad entre la atracción y el desengaño se reitera en algunos relatos como «Planta montés» de Pardo Bazán o el cuento de Narcís Oller titulado «El trasplantado», en el que Daniel, un tahonero de pueblo, atraído por las bellezas de la ciudad condal, abandona su terruño y se traslada a vivir a Barcelona, donde enfermará de melancolía y aburrimiento. La inicial imagen positiva de la ciudad vista a través del personaje de Daniel se trueca en oscuridad, falta de aire y sensación de encierro en las páginas finales del relato. Este texto se incluye, traducido al castellano, en el volumen titulado La mariposa, editado con ilustraciones por Cortezo en Barcelona en 1886, dentro de la Biblioteca Arte y Letras.

5. Citamos siempre, salvo indicación expresa, por la edición de las Obras Completas de Pereda de editorial Tantín.

Anales, 24, 2012, pp. 125-140 
Las animadas descripciones de sus fiestas públicas; la tan cacareada especie de que en Madrid hace cada quisque lo que le acomoda sin que nadie se fije en él, y la plana de anuncios del periódico, según la cual se garantizaba al comprador dinero encima, hiciéronle pensar en la monotonía de las fiestas de su lugar; que en él no se podía tirar un pellizco a una muchacha sin que se contase el lance en todas las cocinas; (pp. 111-112).

Unas páginas después, don Silvestre ha podido llevar a efecto su ansiado viaje a la corte y lo encontramos paseando por Madrid:

Nada de particular halló don Silvestre por las calles, fuera del ruido de los carruajes y del incesante movimiento de la gente. Teníanle el estrépito ensordecido, y tan atolondrado, que tropezaba con todos los transeúntes, y rompió siete cristales de otros tantos escaparates por huir de los coches, pensando que le atropellaban. (p. 117).

Es curioso apreciar que desde las primeras imágenes peredianas de la corte se recurre a la abstracción de formas y se insiste en las sensaciones auditivas captadas por el protagonista, pues tal como ya señaló Bonet: «la corte para Pereda es un simple rumor callejero o unas casas apenas vislumbradas por entre las cortinillas de un carruaje, pues desdeña la mirada panorámica y detallista de un Madrid mundano» (Bonet, 1996: 419).

Una vez que don Silvestre ha llegado a la corte decide conocer los lugares más frecuentados, acompañado por el secretario de su amigo cortesano. Su entrada en cafés y salones de billar, cuyos nombres concretos no se citan nunca, sirve únicamente como ambientación para mostrar una cadena de escenas humorísticas protagonizadas por el paleto, entre las que destaca el episodio del sorbete. A partir de estos momentos comienza a adquirir protagonismo la segunda imagen de Madrid que aparece en el relato, la negativa, en el sentido de que toda la ciudad y sus habitantes están vistos bajo un prisma de decepción. La culminación de este proceso degradatorio es la imagen que tiene Seturas de los parroquianos del café madrileño, a los que cree una «turba de enclenques, famélicos, petardistas, vagabundos y tahúres que poblaban el salón disfrazados de personas decentes» (p. 119), y sobre todo, su desengaño de la vida política del Congreso y del periodismo, que hace exclamar al narrador:

Más ¡oh desengaño! en el palacio de las leyes halló de todo menos discurso. Presenció en el seno de la Asamblea nacional disputas acaloradas, y encontró en los diputados unos hombres de talla común, que tenían el mismo prurito que los periódicos: la inmodestia de decir cada uno de sí propio, corampopulo, lo que todos los demás les negaban: que eran lo mejorcito de la casa, y de lo poco que en virtudes cívicas, y hasta domésticas se encontraba por el mundo. (pp. 121-122). 
A pesar de este desengaño, don Silvestre Seturas no quiere renunciar a conocer los lugares «de puro recreo» (p. 122) de la corte, pero tanto la casa de las fieras, como el Retiro, el paseo del Prado o las puertas de Segovia y Atocha le hacen pensar «que Madrid es una pura ilusión» (p. 123). Después de tal cúmulo de inconvenientes sufridos, decide el aldeano volver a su lugar natal, no sin antes hacerse estas sencillas reflexiones:

¿Dónde está todo lo que yo venía buscando? De todo lo prometido, ¿qué es lo que encuentro? El calor sofocante, el polvo cáustico, el infernal estrépito de los carruajes, el peligro de ser por ellos atropellado, los pillos callejeros y algunos otros mercaderes, el rescoldo de las bebidas, el veneno de los estancos, la brutalidad de los cocheros, el vandalismo de los revendedores, la inhospitalidad de todo el mundo, el materialismo, la usura de la civilización: estas son para mí las únicas verdades de la corte (p. 124).

El narrador perediano está construyendo pues un espacio simbólico lleno de referencias negativas entre las que destacan la crueldad de los cortesanos, manifiesta en las burlas y engaños de que es objeto el montañés (sirvan como ejemplos las anécdotas de la devolución de monedas falsas al aldeano o los pagos que le exigían los guías gallegos por conducirle por las calles de la capital), la falsedad de los Diarios de Sesiones de las cortes, aspecto parcial de la crítica general a la prensa de la época, omnipresente en la obra perediana, la importancia de las apariencias en el mundo social cortesano, e incluso toda una serie de sensaciones físicas negativas del protagonista como el sofocante calor, la escasa sombra que dan los árboles, el polvo de las calles o los ruidos de los coches.

Pero la imagen negativa de Madrid no solamente está vista desde la perspectiva de Seturas, sino que el alto personaje cortesano cuando decide retirarse a la aldea exclama: «yo también reniego de la corte, y que la aborrezco con todos mis sentidos» (p. 126).

En resumidas cuentas, la idealización del espacio cortesano transformada en decepción para el protagonista de este artículo de costumbres, tiene su contrapunto en la idealización del mundo rural montañés que elaborará el narrador a través del madrileño en la segunda parte del relato, basándose en la tradición literaria bucólica, aunque sobre ella proyecte también el narrador perediano un punto de ironía y concluya el relato con esa decepción del cortesano de la vida rural. Con este rechazo final de la aldea, se intenta recalcar de nuevo la tesis que da origen al título del texto: «Suum cuique», cada uno a su lugar.

El mismo itinerario se plantea en Pedro Sánchez (1883) cuando el joven protagonista «evoca la vida cortesana de mediados de siglo» (González Herrán, 1990: 19) y relata su experiencia madrileña. La novela en sus primeros 
capítulos presenta la ansiedad del muchacho aldeano por conocer mundo, pero mientras deja su aldea, los acentos idealizadores del narrador hacen exclamar a Pedro: «iNunca me parecieron más hermosas sus campiñas, ni sus aires más fragantes, ni sus celajes más pintorescos!» (p. 403).

Y a lo largo de las páginas madrileñas de la novela siempre las ventajas de la capital aparecen minimizadas, tanto por la maldad de los cortesanos y las dificultades de ascenso social como porque la ciudad no es lo que había soñado el personaje:

Era por entonces esta, por lo que atañe a sus condiciones exteriores, bien diferente de lo que es hoy; y a la altísima idea que yo tenía de las grandezas de la corte, por razón de la misma pobreza y angostura del pueblo en que yo había vivido siempre, hacía que saltaran a mis ojos... (p. 450).

Las palabras con las que Pedro refleja en los últimos capítulos de la novela su desengaño de todo lo vivido no dejan lugar a dudas al lector acerca de lo fallido de la experiencia madrileña y el deseo de regresar al reducto nativo:

Después de este suceso, érame imposible la residencia en Madrid; su luz, su aire, sus ruidos, todo cuanto me rodeaba allí me decía una misma cosa, sonaba a una misma cosa, me hería de la misma manera: todo me parecía un pregón escandaloso de mi ignominia. Pero ¿adónde ir? ¿A esconderme en las soledades de mi tierra? ¡Qué hijo pundonoroso se atreve a enjugar en el regazo de su madre pesadumbres como la mía! (pp. 664-665).

\section{EL «LODAZAL» CORTESANO ${ }^{6}$}

Un segundo aspecto que se reitera en la visión perediana de la corte es la inmoralidad, asunto sustancial en La Montálvez $z^{\top}$ pero cuyo tratamiento literario inicia el polanquino en La mujer del César, primera de las tres novelitas que integran los Bocetos al temple, calificada por Galdós como «preciosa novela de costumbres urbanas». En este relato el narrador perediano trata con cierta extensión este asunto, que le venía preocupando desde sus inicios literarios. Censura la «supuesta» debilidad moral de la mujer de la alta sociedad, así como su culto a la ostentación, vicios personificados en Isabel, la cuñada del mayorazgo Ramón, protagonista de la novela.

6. Un estudio de la inmoralidad madrileña en las primeras novelas de Pereda puede leerse en Gutiérrez Sebastián: 1998.

7. Aunque en este trabajo haremos alguna referencia al Madrid aristocrático recreado en La Montálvez, no abordaremos el análisis de este aspecto, pendiente de un estudio profundo, pero sobre el que ha vertido una excelente interpretación Laureano Bonet en su edición de esta novela en las Obras completas de Pereda de editorial Tantín cuya referencia bibliográfica completa puede consultarse en la Bibliografía final de este trabajo. 
Esta obra se desarrolla en su totalidad en la capital de España y persiste el mismo propósito ideológico: el de mostrar a Madrid como espacio simbólico que representa al poder central en la ideología del novelista, y que es además y sobre todo «exponente del lujo y los vicios», concretados por supuesto en la clase aristocrática (Madariaga, 1991: 209).

Los espacios madrileños a los que se alude son siempre los del centro de la villa, puesto que las clases populares y su hábitat no tienen cabida en el mundo cortesano que retrata Pereda.

Las primeras referencias espaciales de esta novelita sitúan de nuevo a un montañés en Madrid, en una calle concreta. Sin embargo, nunca se detienen en la descripción del espacio urbano, sino que únicamente se citan los nombres de varias calles, como la calle de Carretas, la Puerta del Sol o la calle del Príncipe, en la que el narrador ubica la casa del hermano de Ramón, un abogado de la alta sociedad madrileña ${ }^{8}$.

La escasez de referencias concretas a los espacios madrileños se contrapone a la abundancia de resabios ideológicos contra dichos lugares, puesto que ya en el primer capítulo de La mujer del César el narrador previene al lector contra Madrid diciendo que es el «centro del lujo, la galantería y los grandes vicios de toda la nación.» (p. 51), y precisamente estos elementos serán blanco de las críticas de la voz narradora durante todo el resto del relato, bien a través de digresiones o bien a través de su portavoz ideológico en el texto, el mayorazgo Ramón.

Respecto al primero de estos elementos, el lujo, el narrador aludirá a él en varios momentos de la novela, como en el instante en el que se relata la llegada de Ramón al interior de la casa de su hermano, o bien cuando se refiera a la joyería, lugar de exhibición y murmuración al que acude asiduamente el inmoral Vizconde del Cierzo. La mujer de la aristocracia, que competía con sus iguales en la ostentación de joyas y vestidos en el ámbito de las fiestas de sociedad, era la principal cliente de unos establecimientos que aumentaron con profusión en este período de auge de la burguesía mercantil. Unos años después de la publicación de la novela, la prensa se hacía eco del aumento en el número de estos establecimientos en la capital de España, así como del lujo que en ellos se apreciaba:

El centro de Madrid [...] se ve invadido por joyerías. El escaparate más humilde de estos establecimientos de lujo, ostenta en alhajas un capital de muchos miles de duros. ¿Qué prueba el desarrollo de este comercio sino la ruina de muchas fortunas particulares? (Nulema, 1884: 157-158).

8. En esta misma calle situará también el narrador polanquino la casa de los Valenzuela, la familia aristócrata cortesana de la novela Pedro Sánchez. 
La galantería, el segundo aspecto en el que se centra la censura perediana del Madrid cortesano, será el desencadenante del conflicto matrimonial, y el ambiente propicio escogido por el narrador para mostrar las funestas consecuencias morales de los galanteos ambiguos del Vizconde con Isabel, es una fiesta de sociedad celebrada en casa de la condesa de Rocaverde. En el capítulo VII de la novelita encontramos a través de pinceladas sueltas una caracterización de este espacio que insiste más en los tipos y en las actividades desarrolladas por estos que en datos descriptivos concretos:

Allí se hacía música; allí se declamaba, poniéndose a veces, en un teatrito al caso, por las jóvenes más pudorosas y los jóvenes más formales, lo más aplaudido del repertorio contemporáneo... francés, por supuesto; y allí, finalmente, se celebraban esos bailes pintorescos que tanto dieron que hacer a los sastres, a la modistas, y al sentido común, [...] (p. 93).

La censura de la galantería de los personajes masculinos de los salones aristocráticos de Madrid lleva, además, a la caricaturización exagerada de estos tipos por parte del narrador:

Pululando, culebreando, plegándose como mimbres o irguiéndose como alcornoques (no siempre han de ser palmeras los términos de comparación), veíase al «distinguido» pollo [...], cruzando los salones, o retorciéndose el mostacho enfrente de cada espejo, o adoptando posturas académicas en cada esquina, al hombre parco en saludar, de ancho tórax y pescuezo corto, $[\ldots]$ Hojeando los álbumes en los gabinetes, o chupando los puros de la casa en las salas de fumar, el hombre de negocios, el general encanecido en cien pronunciamientos, digo batallas, el periodista de nota, etc., etc., etc. (p. 95).

Otro detalle en el que se centra la crítica perediana es el despilfarro del que hacían gala las clases aristocráticas madrileñas ${ }^{9}$, para lo que se sirve también del episodio de la fiesta de sociedad. A partir de este espacio cortesano, en el que reina la superficialidad y el lujo, conseguido en palabras del narrador «entre angustias de bolsillo y exigencias de acreedor» (p. 93) se repite el tema de la falsa apariencia y se censura ácidamente el gasto superfluo, un asunto que ya había abordado Pereda en sus primeros ensayos dramáticos, concretamente en su comedia Marchar con el siglo (1863).

Esta pintura de Madrid como centro de corrupción y malas costumbres se reitera en las páginas de Pedro Sánchez; incluso se muestra cómo se difunden esos vicios desde la corte a las provincias ${ }^{10}$. Así, cuando Pedro es nom-

9. El tema de la apariencia y la ostentación de la mujer aristócrata y burguesa aparece reiteradamente en la novelística española del XIX; en novelas como La de Bringas de Galdós se convierte en hilo conductor de la trama y base en la que sustentar la crítica social.

10. Stephen Miller reformuló estos tópicos peredianos señalando que: «Madrid es el centro del país en muchos sentidos y su influencia se siente, por bien o por mal, en todas 
brado gobernador de provincia, el lujo y la ostentación que desde Madrid ha importado su familia a la pequeña ciudad se recrean con los mismos tintes moralizantes y satíricos con los que se pintaban los lujos de la burguesía madrileña:

Con la entrada del otoño comenzaron los espectáculos nocturnos; y con este motivo, para lucirse en primera fila, allá van vestidos y perifollo y tocados; y como las damas de la ciudad iban tomando a Clara por modelo en el vestir y en el andar, ella se complacía en lucir en cada exhibición una cosa nueva [...]. La condesa del Rábano recibía los miércoles, y los señores de Cerneduras los viernes; y como aquellas reuniones eran verdaderos certámenes de lujo, y Clara concurría a ellas y era la más mirada y atendida por ser en el pueblo la mujer de moda, ¿cómo no había de dar en cada caso la necesaria novedad a su elegante atavío? (p. 633).

Pero sin duda es en las páginas de La Montálvez en las que llega a su culminación el prejuicio moral perediano contra la corte, lo que Laureano Bonet denomina: «el solivianto ideológico contra Madrid» (p.443), como vemos otro de los leiv motiv presentes desde sus inicios literarios.

\section{MADRID VIVIDO, LEÍDO Y EVOCADO}

Pese a que el Madrid de las primeras narraciones peredianas está más cercano biográficamente a la experiencia en la corte de su autor (recordemos que el polanquino vive en la capital entre 1852 y $1854^{11}$ y que los primeros relatos

partes. Pero, se percibe una anomalía: este centro, bastante extranjerizado y moralmente dañado, dista mucho de ofrecer un ejemplo muy recomendable al resto del país en todo lo socio-político.» (Miller, 1988:236).

11. Las dos biografías que hasta el momento se han escrito sobre el polanquino (Gullón, 1944 y Madariaga, 1991) repasan su experiencia cortesana indicando que llegó a la capital en 1852 enviado por su familia para ingresar en la Academia de Artillería, que se alojó en una pensión en la calle del Prado, cerca del Teatro Español y del café de la Esmeralda un famoso mentidero de la época frecuentado por estudiantes y escritores (Gullón, 1944: 30-31), al que asistían entre otros Antonio Trueba, quien andando el tiempo redactaría el prólogo a las Escenas montañesas y que frecuentó los teatros y cafés de moda, desatendiendo sus estudios. Esta actitud estuvo motivada tanto por su aversión a las matemáticas como por la influencia que sobre él ejercieron sus compañeros de pensión, que le hicieron inclinarse hacia sus aficiones literarias, concretadas en el inicio de su carrera como escritor con la comedia en verso La fortuna en un sombrero, fechada en febrero de 1854. En ese mismo año Pereda sería testigo de los graves sucesos políticos producidos como consecuencia de la sublevación de O’Donnell y la Vicalvarada, lo que unido a su falta de vocación para la carrera de artillero, le impulsó a regresar a Santander, regreso que le causaría una sensación negativa, porque vuelve sin haber cumplido sus expectativas profesionales, y porque su vuelta supone el retorno a un Santander provinciano que se le antojará al joven Pereda insípido y aburrido después de las múltiples distracciones que le había ofrecido el mundo cortesano (Madariaga,

Anales, 24, 2012, pp. 125-140 
de ambientación madrileña están en el volumen de Escenas Montañesas de 1864) la recreación más concreta y detallista de la ciudad no aparece en esos primeros textos, sino en las páginas de Pedro Sánchez, escrita casi treinta años después de aquellas vivencias. En esas primeras novelas madrileñas la ciudad retratada ofrece al lector una impresión de irrealidad, muy alejada de la minuciosa pintura de la vida madrileña que presentan otros escritores como Benito Pérez Galdós. Esta impresión se debe a la escasez de detalles y al predominio de la moralización sobre el descripcionismo, aspecto que nunca descuida el narrador perediano cuando recrea el mundo montañés.

Pero en Pedro Sánchez, quizá por la perspectiva autobiográfica de esa novela, por lo que tiene ese relato de rememoración de experiencias de juventud y por el condicionante ideológico: la lección que un Pedro desengañado que vuelve a la aldea quiere mostrar para escarmiento de los lectores (González Herrán, 1990:19), se pintan con cierto detalle los espacios urbanos y las circunstancias histórico-literarias que han propiciado la experiencia vital negativa del protagonista.

Se despliega en sus páginas un riquísimo entramado de calles, posadas, cafés, tertulias literarias, reuniones sociales, bailes, oficinas ministeriales, teatros, redacciones de prensa, revueltas callejeras, despachos de los políticos ${ }^{12} \ldots$ y especialmente interesante $-\mathrm{y}$ no ajena a esa lección moral que pretende el relato- es la primera imagen de la corte que percibe Pedro, velada por las desengañadas y ácidas palabras del cesante de Don Serafín, su compañero de viaje en la diligencia de Las Peninsulares:

-Aquello es Madrid -añadió mirando hacía allá asido con las dos manos al marco de la ventanilla, y bamboleando el encorvado cuerpecillo, según lo pedían los tumbos y vaivenes que daba la diligencia en su rápido y estruendoso descenso-. ¡Ah! ¡si yo tuviera poder para tanto!... Un recadito secreto a las gentes honradas para que escurrieran el bulto; luego una lluvia espesa de pólvora fina; en seguida otra lluvia de rescoldo... y como en la gloria todos los españoles (pp. 414-415).

Los primeros recorridos del joven montañés hasta la pensión estudiantil de la calle del Caballero de Gracia, por la calle Alcalá y de la Montera y sus posteriores paseos acompañado por sus nuevos guías y paisanos que muestran

1991:73-75).Al volver a Santander, en sus colaboraciones periodísticas en La Abeja Montañesa y El Tío Cayetano, dos diarios satíricos, comenzará a atacar a Madrid, con la rigidez censórea de un Catón provinciano (García Castañeda, XXXIV: 1989) y se inicirá entonces en sus escritos una vena de antimadrileñismo de la que nunca se apartará en su carrera literaria.

12. Un análisis de la imagen de los políticos en algunos textos del polanquino puede verse en Gutiérrez Sebastián, 2007. 
a Pedro cómo pasar el día en la capital con exiguos dineros y muchas ganas de novedad y diversión, tienen un tono picaresco que ha subrayado la crítica (González Herrán, 1990: 20-23).

Muy pronto la literatura hace acto de presencia en la vida de Pedro y en el discurso narrativo de su creador: las referencias a las lecturas con las que llena sus horas en la posada el personaje y su asistencia a $\operatorname{los}_{\text {teatros }}{ }^{13} \mathrm{y}$ a las tertulias son buena muestra de ello.

Entre los capítulos VIII y XXII se relata la tensión interior del personaje, desde el desconcierto inicial en el que es patente la hostilidad del espacio urbano, hasta el momento en el que consigue un empleo como redactor de un periódico y el triunfo social en las tertulias. Simbólicamente el narrador escoge ciertos espacios para mostrar ese proceso de ascenso social del personaje, presentando su primer peregrinar por los modestos cafés y mostrando ya en páginas posteriores su presencia en tertulias literarias de renombre.

Quizá la crítica ha puesto demasiado énfasis en el elemento autobiográfico que sin duda está presente en estas páginas, y por eso, yo quisiera poner el acento en las fuentes literarias que podemos rastrear en ellas. Destaca, sin duda, la literatura costumbrista, especialmente el Mesonero de Escenas Matritenses, o Mejoras de Madrid, los artículos de Larra o Madrid por dentro y por fuera de Eusebio Blasco (1873) que le aportan a Pereda elementos de ambientación, especialmente tipos como los pintorescos parroquianos de los cafés, las señoritas casaderas, los estudiantes, y paletos de las distintas regiones españolas, los aspirantes a literatos y periodistas, los intrigantes, los cesantes, los políticos de nota... y también recursos literarios con los que abordarlos, en particular la ironía, el juego de perspectivas, la atención a lo óptico y la moralización. Sirvan como ejemplos la recreación de los cafés en el capítulo $\mathrm{XV}$ del relato y las escenas de las tertulias.

La pintura del café se inicia con una digresión moralizante muy en línea con las prevenciones de los escritores costumbristas acerca de la importancia de los cafés para los madrileños y los aspectos negativos de esas cátedras en las que se discute de lo divino y lo humano y a las que asisten una pléyade de tipos costumbristas: «La asistencia al café era entonces, y creo que continuó y continúa siéndolo, una verdadera necesidad para la gente madrileña» (p. 461).

13. Las referencias a los teatros madrileños así como la alusión en conversaciones de los personajes a actores y obras dramáticas del momento son constantes en la obra. 
Tras estos párrafos de reconvención, el narrador pinta una escena costumbrista protagonizada por una galería de tipos, presidida por la figura de Agamenón:

Era grandote y áspero, áspero de todo: de voz, de genio, de pelos, de cutis, de palabras y de meollo. Había sido teniente de movilizados, contaría a la sazón medio siglo, era manchego y solterón y llevaba veinte años en Madrid comiéndose descansadamente el escaso producto de unos censos o cargas de justicia, o no sé qué (p. 462).

Este tipo, al que define el narrador como «amante bestial de Madrid por fuera» (pág.462), en expresión que recuerda a la obra Madrid por dentro y por fuera de Eusebio Blasco (1873) protagoniza algunas de las escenas costumbristas teñidas de humor y en las que se pinta el estreno de Pedro en la cátedra del café de la Esmeralda.

Y de nuevo se hace patente el resorte de reconvención moral del costumbrismo cuando la voz narradora relata la marcha del personaje del modesto café de La Esmeralda y su asistencia al Suizo ${ }^{14}$ :

tanto llegué a inflarme, que esquivaba la compañía de Matica, cuyas sinceridades eran mi castigo, y abandoné la tertulia del modesto café de La Esmeralda y la sociedad de mis paisanos, y me hice concurrente al Suizo entre la bohemia de la gacetilla y de la dramática al menudeo; y allí cobré afición a la disputa, y llegué a distinguirme por una facilidad de palabra verdaderamente espantosa (p.528).

Respecto a la recreación de las tertulias, también deudora del costumbrismo, destaca la visita de Pedro a la casa de don Magín de los Trucos, una escena costumbrista que como indica Francisco Pérez en la nota 43 a su edición de la novela en las Obras Completas de Editorial Tantín encierra un propósito de crítica social a la pequeña burguesía madrileña, en plena sintonía con las novelas galdosianas.

Junto a la importancia del costumbrismo en la recreación de los ambientes madrileños, podemos apuntar otra posible influencia literaria. Se trata de una novela que cita la propia voz narradora de Pedro, Un viaje al infierno (1848-49), del motrilense Juan de Ariza, escritor que había llegado a Madrid buscando la gloria, como Pereda y su alter ego Pedro Sánchez. En la novela cuando Pedro, metido a crítico literario, pinta el panorama de las letras en ese momento alude a este texto: «y se elogiaban una de Juan de Ariza, Un viaje al

14. Como ha indicado Romero Tobar, los cafés fueron el lugar indispensable de exhibición y convivencia de la bohemia literaria y por eso el personaje acude a este café Suizo cuando llega a formar parte de esa bohemia acude a la nueva tribuna (Romero Tobar, 1993:41). 
infierno (1848-49), sátira del Madrid entonces, en que había muchos anagramas demasiado transparentes.» (p. 524). Podemos deducir de estas palabras que el novelista conocía esta novela y pueden no ser casuales los puntos de contacto entre ambos textos ${ }^{15:}$ el modo autobiográfico, la pintura de la vida de un aspirante a escritor en Madrid y el tono satírico, demasiado exagerado en la novela de Ariza y menos en la de Pereda ${ }^{16}$ son algunos de ellos.

\section{CONCLUSIONES}

Tras este recorrido por las referencias a Madrid en las páginas de algunos de los relatos peredianos podemos indicar que la hostilidad del novelista de Polanco hacia el mundo madrileño se concreta en sus textos de modo diferente: en las primeras novelas, la corte es un espacio abstracto sobre que el planea la sombra del prejuicio moral negativo, y esta misma idea se reiterará en $L a$ Montálvez, pero en Pedro Sánchez el narrador se dedica a relatar la experiencia madrileña y la ciudad presentada tiene fisonomía propia, transitan por sus calles, cafés y tertulias caracteres de ficción y recreaciones literarias de personajes reales y se transmite al lector una sensación de realidad que no encontramos en los textos anteriores.

Pero, pese a estas diferencias en el tratamiento del espacio urbano cortesano en los textos narrativos del polanquino, una serie de elementos permanecen

15. En un trabajo que he realizado y que está pendiente de publicación explicaré con más detalle estas similitudes entre ambos relatos.

16. Ariza vivió en la capital en 1844 y 1855 hasta que marcha a Cuba al año siguiente. Allí triunfa como periodista y como escritor toca todo los géneros, especialmente la narrativa y el teatro y precisamente en Un viaje al infierno cuenta de modo autobiográfico sus experiencias en la capital. Es una novela de 1848-49 en la que se hace una sátira de la corte vista a través de un personaje que junto con el diablo vive la experiencia madrileña. En esta novela, escrita en primera persona, los individuos descritos, verdaderos personajes clave, aluden a ciudadanos reales del Madrid de la época, en su mayoría conocidos por el autor. El prologuista, un supuesto amigo de Nazario Palma de Jura (anagrama de Juan de Ariza Palomar), advierte al lector que, siguiendo las instrucciones de este, va a publicar las cartas que le remita Nazario desde Dramalla, Corte del Infierno. Con este artificio, comienza la novela. Esta narra las peripecias del joven escritor Nazario, quien, aconsejado en Granada por un individuo homónimo que se le parece como una gota de agua a otra (luego se sabrá que es un diablo), decide viajar al Infierno, cuya capital Dramalla es un espejo de Madrid. Con un lenguaje al principio fresco, vivo e irónico, a veces lleno de gracia, cuenta en clave la vida de los literatos y de la sociedad política madrileña, verdadera corte de los milagros, como él mismo la llama, asaltada por incesantes y repetidas crisis e intrigas. Sin embargo, poco a poco, la novela va perdiendo interés debido a la repetición de las situaciones y a la similitud de los personajes, y, además, a causa de la sustitución progresiva del acertado tono satírico por ese otro acento en exceso melodramático.

Anales, 24, 2012, pp. 125-140 
constantes en él: la confrontación entre la degradación del mundo cortesano y la idealización de la aldea, tratada literariamente a partir del costumbrismo, la crítica a las clases aristocráticas y la denuncia de sus vicios como el lujo, la superficialidad, la hipocresía, la corrupción política, el despilfarro y la inmoralidad entre otros, frente a los que sitúa la idealización del reducto rural, refugio en el que se conservan las tradicionales virtudes que presiden el ideario regionalista del polanquino y la aspiración perediana a contar con un puesto de honor en la literatura regionalista, que le arrastraba hacia al antimadrileñismo con el que consiguió el aplauso de los lectores de esas literaturas periféricas que tanta importancia tuvieron en la cultura española del último cuarto del siglo XIX.

\section{BIBLIOGRAFÍA}

ARIZA, Juan, Un viaje al infierno, Madrid, Imprenta de don José María Alonso, 1849.

BLASCO, Eusebio (dir.). Madrid por dentro y por fuera. Guía de forasteros incautos, edición de María Ángeles Ayala, Madrid, Biblioteca Nueva-Universidad de Alicante, 2008.

ClaRKe, Anthony H., Pereda paisajista (El sentimiento de la naturaleza en la novela española del siglo XIX, Santander, Institución Cultural de Cantabria, 1969.

García CaStañeda, Salvador, Del periodismo al costumbrismo. La obra juvenil de Pereda (1854-1878), Alicante, Publicaciones de la Universidad de Alicante, 2004.

GARCÍA CASTAÑEDA, Salvador, «Del periodismo al costumbrismo: la obra juvenil de Pereda (1854-1878)», Aula de Letras, 1 (2006), pp. 105-107.

GARCÍA CASTAÑEDA, Salvador, «Terpsícore montañesa. Bailes y bailarines en el Santander decimonónico», Anales de Literatura Española, 18 (Serie monográfica, $\mathrm{n}^{\circ}$ 8): Romanticismo español e hispanoamericano. Homenaje al profesor $\mathrm{Er}$ manno Caldera, ed. Enrique Rubio Cremades, Universidad de Alicante: Área de Literatura Española, 2005, pp. 181-199.

GONZÁLEZ HERRÁn, José Manuel, «Érase un muchacho (de la corte) que emprendió un viaje (a la aldea...) Pereda, Peñas arriba», en Peñas arriba, cien años después, Sociedad Menéndez Pelayo, Santander, 1997.

GoNZÁLEZ HERRÁn, José Manuel, «La aventura del joven que viaja (entre corte y aldea), en la ficción de José María de Pereda» en 2006. Recordando a Pereda, Caja Cantabria, Gráficas Gráficas Quinzaños, Santander, 2007, pp. 61-73.

GonZÁlez Herrán, José Manuel, «La revolución de julio de 1854 en la novela: José María de Pereda, Pedro Sánchez (1883). Benito Pérez Galdós, La Revolución de Julio (1903)», en Actas del Quinto Congreso Internacional de Estudios 
Galdosianos (1992 [sic, por 1993]), I, Las Palmas de Gran Canaria: Ediciones del Cabildo Insular de Gran Canaria, (1995), pp. 383-392.

GONZÁlez HerRán, José Manuel, La obra de Pereda ante la crítica literaria de su tiempo, Santander, Colección. Pronillo, 1983.

Gullón, Ricardo, Vida de Pereda, Madrid, Editora Nacional, 1944.

GUTIÉRREZ SEBASTIÁN, Raquel, «La ciénaga madrileña»: La imagen de Madrid en las primeras narraciones de José María de Pereda» en Congreso Internacional. Ciudades vivas/ciudades muertas. Espacios urbanos en la literatura y el folklore hispánicos. Medina del Campo. Junio 1998, pp. 135-147.

GutiéRrez SEbastián, Raquel, «Poder, deseo y política en dos novelas de Pereda, Don Gonzalo y Pedro Sánchez» en Congreso Internacional Deseo, poder y política en la cultura hispánica, MCGill- University y Universitas Castellae. Colección Cultura Iberoamericana. Número 25, Valladolid, 2007, pp.85-96.

GUTIÉRREZ SEBASTIÁN, Raquel, «Mujer y trasgresión en las primeras novelas de José María de Pereda» en Congreso Internacional Las representaciones de la mujer en la cultura hispánica. Valladolid, 7-9 de julio de 1999, pp.193-203.

GUTIÉRREZ SEBASTIÁN, Raquel, «Política y políticos en las primeras novelas de Pereda» en Crítica Hispánica. Mónica Fuertes y Gregorio Martín (eds.). Duquesne University, en prensa.

LÓPEZ DE ABIADA, José Manuel, «Etnocentrismo, prejuicio y xenofobia en la obra de José María de Pereda: Del regionalismo provinciano al paternalismo localista», Boletín de la Biblioteca de Menéndez Pelayo, LXII, (1986), pp. 163-186.

Madariaga de la CAmpa, Benito, Pereda. Biografía de un novelista, Santander, Ediciones de la Librería Estvdio, 1991.

MiLLER, Stephen, «Madrid y la problemática regionalista en Pereda y Galdós», B.B.M.P., LXIV, (1988), pp. 223-251.

Nulema, Revista. La Ilustración Católica, Madrid, 5-3-1884, pp-157-158.

Oller, Narcís, La mariposa, traducción de Felipe B. Navarro. Barcelona, Biblioteca Arte y Letras, 1886.

Pereda, José María de, Pedro Sánchez, Edición de José Manuel González Herrán, Madrid, Espasa Calpe, Colección Austral, 1990.

PÉREZ GuTIÉRREZ, Francisco, El problema religioso en la generación de 1868, Madrid, Taurus, 1975.

Romero Tobar, Leonardo, «En los orígenes de la bohemia: Bécquer, Pedro Sánchez y la revolución de 1854», en Bohemia y literatura (de Bécquer al modernismo), Pedro M. Piñero y Rogelio Reyes (eds.), Sevilla, Universidad de Sevilla, 1993, pp. 27-49.

Pereda, José María de, Obras completas, dirigidas por Anthony H.Clarke y José Manuel González Herrán:

Tomo I: Escenas montañesas, edición, introducción y notas de Salvador García Castañeda, Santander, Tantín, 1989. 
Tomo II: Tipos trashumantes, edición, introducción y notas de Salvador García Castañeda, Santander, Tantín, 1989.

Tomo III: Bocetos al temple, edición de José Manuel González Herrán y Noël M. Valis, introducción y notas de Noël M. Valis, Santander, Tantín, 1990.

Tomo V: Pedro Sánchez, edición de José Manuel González Herrán, introducción y notas de Francisco Pérez Gutiérrez, Santander, Tantín, 1992.

Tomo VI: La Montálvez, introducción y notas de Laureano Bonet, Santander, Tantín, 1996.

Tomo IX: Pachin González. Miscelánea I, edición, introducción y notas de Salvador García Castañeda, Santander: Ediciones Tantín, 2008.

Fecha de recepción: 28-12-2011

Fecha de aceptación: 15-04-2012 